\title{
Pelatihan Pembuatan Alat Evaluasi Berbasis ICT Menggunakan Wondershare Quiz Creator Bagi Guru-Guru SMPS Katolik Aurora
}

\author{
Cecilia Novianti Salsinha1, Talisadika Serrisanti Maifa², Hendrika Bete ${ }^{3}$ \\ 1,2,3Universitas Timor \\ e-mail: ${ }^{1}$ ceciliasalsinha@unimor.ac.id, 2talisadikamaifa@unimor.ac.id, \\ 3hendrika@unimor.ac.id
}

\begin{abstract}
Abstrak
Pada masa dimana Indonesia sedang masuk dalam masa transisi covid-19, peran guru sangat dibutuhkan dalam proses pembelajaran. Berdasarkan hasil wawancara dengan Kepala Sekolah, proses pembelajaran lebih difokuskan pada penggunaan Whatsapp dan siswa cenderung belajar mandiri. Hal ini sangat berdampak bagi pemahaman siswa oleh karena siswa hanya belajar menggunakan buku yang sudah dibagikan oleh guru. Salah satu cara yang dapat digunakan adalah dengan pemanfaatan software Wondershare Quiz Creator (WQC) yang dapat digunakan untuk membuat alat evaluasi yang menarik dan interaktif bagi siswa. Aplikasi ini juga dapat digunakan dengan mudah, serta menghasilkan output yang fleksibel. Dalam soal pun dapat disisipkan dengan berbagai media pendukung seperti gambar, suara, maupun video. Kelebihan lain yaitu dapat digunakan untuk belajar secara mandiri oleh siswa. Salah satu langkah yang dilakukan tim pengabdi yakni dengan melakukan pelatihan bagi guruguru pada SMPS Katolik Aurora Kefamenanu. Pelatihan dimulai dengan tahap persiapan dimana pengabdi bertemu dengan Kepala Sekolah untuk menentukan jadwal pengabdian dan persiapan modul. Pengabdian dilaksanakan selama 4 hari dengan peserta pengabdian berjumlah kurang lebih 17 orang. Kegiatan ini disambut positif oleh pihak sekolah, guru-guru juga merasa memperoleh pengalaman baru membuat alat evaluasi yang lebih menarik. Meskipun 70,59\% guru membutuhkan waktu yang lama untuk membuat soal namun seluruhnya merasa software ini menarik dan mudah digunakan serta diyakini menambah semangat siswa ketika mengerjakan soal ujian. Hasil percobaan penggunaan alat evaluasi pada siswa juga memberikan hasil $78,57 \%$ siswa merasa software ini dapat menambah semangat dalam mengerjakan soal dan $92,87 \%$ siswa merasa software ini menarik dan mudah digunakan serta sesuai dengan minat mereka.
\end{abstract}

Kata kunci: Alat Evaluasi, Wondershare Quiz Creator, ICT,Software, Pembelajaran Daring

\section{Abstract}

At a time when Indonesia is entering the COVID-19 transition period, the role of teachers is very much needed in the learning process. Based on the results of interviews with the Principal, the learning process is more focused on the use of Whatsapp and students tend to learn 
independently. This has an impact on students' understanding because students only learn to use books that have been distributed by the teacher. One way that can be used is the use of Wondershare Quiz Creator (WQC) software which can be used to create interesting and interactive evaluation tools for students. This application is also easy to use, and produces flexible output. In the question can also be inserted with various supporting media such as images, sound, and video. Another advantage is that it can be used for independent study by students. One of the steps taken by the service team was to conduct training for teachers at the Aurora Kefamenanu Catholic Junior High School. The training begins with the preparation stage where the servant meets with the Principal to determine the schedule of service and module preparation. The service is carried out for 4 days with approximately 17 service participants. This activity was welcomed positively by the school, the teachers also felt that they had gained new experiences in making evaluation tools more interesting. Although $70.59 \%$ of teachers took a long time to make questions, all of them felt that this software was interesting and easy to use and believed to increase students' enthusiasm when working on exam questions. The experimental results of using evaluation tools on students also gave the results that $78.57 \%$ of students felt that this software could increase their enthusiasm in working on questions and $92.87 \%$ of students felt that this software was interesting and easy to use and according to their interests.

Kata kunci: Evaluation Tools, Wondershare Quiz Creator, ICT, Software, Online Learning

\section{Pendahuluan}

Kemajuan teknologi saat ini membawa dampak yang sangat luas termasuk dalam dunia pendidikan. Hal ini dapat dilihat dari semakin berkembangnya teknologi computer dan teknologi internet baik itu dalam bentuk perangkat lunak maupun perangkat keras. Kemajuan teknologi telah menyediakan berbagai macam perangkat lunak yang dapat digunakan untuk mempermudah dalam membuat media pembelajaran seperti Microsoft Power Point, Macromedia Flash, Adobe Flash dan salah satu software yang sedang digunakan oleh banyak guru yaitu Wondershare Quiz Creator (Rahmawati, 2017)

Berdasarkan hasil wawancara dengan Kepala Sekolah SMPS Katolik Aurora, proses pembelajaran selama wabah covid-19 lebih difokuskan pada penggunaan Whatsapp dan siswa cenderung belajar mandiri. Hal ini tentu sangat berdampak bagi pemahaman siswa oleh karena siswa hanya belajar menggunakan buku teks yang ada dengan soal yang ada dalam buku teks yang sudah dibagikan oleh guru. Hal inipun cenderung membuat siswa merasa bosan dalam mengikuti proses pembelajaran.

Dalam keadaan seperti sekarang yang mana Indonesia sedang masuk dalam masa transisi covid-19, peran guru sangat dibutuhkan dalam proses pembelajaran. Guru tidak hanya berperan untuk mengarahkan siswa sesuai dengan bidang ilmunya, namun dituntut kreatif dalam mengelola kelas sehingga siswa tidak merasa bosan ketika mengikuti pembelajaran terutama pembelajaran daring. Guru perlu menyediakan media pembelajaran yang menarik minat siswa dalam proses pembelajaran (Sefpratama, 2015). 
Salah satu software yang dapat digunakan untuk membuat media pembelajaran yang menarik dan interaktif bagi siswa adalah Wondershare Quiz Creator (WQC). Menurut Emi dalam (Sefpratama, 2015) wqc adalah aplikasi yang dapat digunakan untuk membuat soal multimedia interaktif. Aplikasi ini dapat membuat kuis yang interaktif dengan mudah, serta output yang fleksibel. Penggunaan WQC dalam pembuatan soal tersebut sangat familiar/user friendly, sehingga sangat mudah digunakan dan tidak memerlukan kemampuan bahasa pemrograman yang sulit untuk mengoperasikannya (Rahmawati, 2017). Hasil soal yang disusun bisa disimpan dalam bentuk flash standalone atau bisa berdiri sendiri di website. Dengan $W Q C$, guru dapat menyusun berbagai bentuk soal dan memiliki level yang berbeda, mulai dari bentuk soal pilihan ganda (multiple choice), benar/salah (true/false), penjodohan (matching), pengisian kata (fill in the blank) dan lain-lain. Dalam soal pun dapat disisipkan dengan berbagai media pendukung seperti gambar, suara, maupun video (Purnanto \& Mahardika, 2017).

(Purnanto \& Mahardika, 2017) juga menjelaskan bahwa WQC memiliki beberapa fasilitas yang menjadi kelebihannya yaitu (1) fasilitas umpan balik (feed-back) berdasar atas respon/jawaban dari peserta tes; (2) fasilitas yang menampilkan hasil tes/score dan langkah-langkah yang akan diikuti peserta tes berdasar respon/jawaban yang dimasukkan; (3) fasilitas mengubah teks dan bahasa pada tombol dan label sesuai dengan keinginan pembuat soal; (4) fasilitas memasukkan suara dan warna pada soal sesuai dengan keinginan pembuat soal, dan (5) fasilitas hyperlink; yaitu mengirim hasil/score tes ke email atau LMS; (6) fasilitas pembuatan soal random, (7) fasilitas keamanan dengan User account/password, (8) Fasilitas pengaturan tampilan yang dapat di modifikasi, dll.

Kelebihan lain dari media pembelajaran interaktif berbasis $W Q C$ ini yaitu dapat digunakan untuk belajar secara mandiri oleh siswa. Software ini turut mendukung proses pembelajaran selama masa transisi oleh karena pembelajaran dilakukan secara bergantian antara tatap muka dan pembelajaran mandiri siswa. Software evaluasi ini juga berbentuk aplikasi yang dapat dan sangat mungkin untuk dapat diterapkan baik di kelas maupun di rumah. Guru dapat memanfaatkan software ini terlebih dalam pembelajaran non tatap muka mengingat jam pelajaran di sekolah yang berkurang. Selain itu software ini sangat mudah digunakan terutama dalam pengacakan soal jika ingin digunakan untuk ujian atau tes online. Hal ini tentunya sangat mengurangi tingkat kecurangan siswa dalam ujian atau tes (Meryansumayeka et al., 2018).

Oleh karena banyak kelebihan dari software ini dan kemudahan dalam penggunaan, selain itu SMPS Katolik Aurora sudah dilengkapi dengan lab computer yang berisi 50 unit komputer maka penulis mengadakan pelatihan penggunaan WQC sebagai alat evaluasi berbasis ICT Menggunakan bagi Guru-guru SMPS Katolik Aurora. Pelatihan ini diharapkan dapat memberikan suatu wawasan baru bagi para guru dalam membuat alat evaluasi belajar yang tidak hanya inovatif tetapi juga menyenangkan bagi siswa. Hal ini sejalan dengan penelitian Dafitri yang menyimpulkan bahwa WQC dapat membantu pihak sekolah dalam pelaksanaan seleksi ujian saringan masuk di SMA Swasta Harapan I Medan (Dafitri, 2017). Selanjutnya Roliska dkk 
mengembangkan media evaluasi pembelajaran dengan menggunakan WQC dan mendapati bahwa secara keseluruhan media evaluasi tersebut layak berdasarkan pedoman kriteria kelayakan (Candra Rolisca \& Achadiyah, 2014). Demikian juga dengan hasil penelitian (Meryansumayeka et al., 2018) yang mana kuis interaktif yang dikembangkan dengan menggunakan wqc dinyatakan valid dan praktis. Demikian juga dengan (Kholifah \& Rubhiyanti, 2018) medesain evaluasi seara online berbasis wondershare yang valid dan layak digunakan.

Pelatihan WQC ini tidak hanya dilakukan kepada guru tetapi diujicobakan juga kepada siswa dengan bantuan 2 orang mahasiswa yang ikut terlibat dalam kegiatan pelatihan. Dengan demikian diharapkan mahasiswapun belajar mengenai alat evaluasi WQC sebagai bagian dari peningkatan softskill menghadapi era digital yang semakin berkembang.

\section{Metode}

Pelatihan dilaksanakan di SMPS Aurora dalam rentang waktu dari Mei hingga Oktober 2021. Untuk mewujudkan tujuan pengabdian, maka langkah-langkah yang ditempuh adalah sebagai berikut:

1. Tahap Persiapan

a. Melakukan koordinasi (pertemuan) dengan pihak sekolah, dalam hal ini Kepala Sekolah SMPS Katolik Aurora, untuk mendiskusikan model soal yang paling dibutuhkan sekolah sehingga pelatihan ini lebih terarah pada kebutuhan guru-guru SMPS Katolik Aurora.

b. Mempersiapkan alat dan bahan meliputi persiapan perangkat pengabdian merujuk pada pengabdian (Widarma \& Saleh, 2020) yaitu Modul Pelatihan, Contoh soal yang akan dibuat dalam bentuk digital, soal latihan bagi para guru serta kuesioner respon guru dan respon siswa baik terhadap penggunaan software $W Q C$.

\section{Tahap Pelaksanaan}

Pelatihan Pembuatan Media Pembelajaran Interaktif Berbasis ICT Menggunakan Wondershare Quiz Creator yang dibagi menjadi 4 hari dengan rincian yaitu diawali dengan proses penginstalan software dan persiapan Lab pada hari pertama. Selanjutnya hari kedua dilanjutkan dengan memberikan materi mengenai software WQC, pengenalan bagian-bagian dari software, beberapa menu penting dalam software WQC serta proses pembuatan soal yang telah disediakan oleh pengabdi dengan berbagai macam tipe soal sesuai dengan kesepakatan dengan pihak sekolah. Pelatihan hari kedua ini diakhiri dengan pemberian kuesioner respon guru untuk mengetahui sejauh mana respon guru terhadap kegiatan pengabdian dan software yang diberikan serta kesepakatan untuk melakukan kegiatan tindak lanjut.

\section{Tahap Tindak Lanjut}

Pada tahap ini tim pengabdi melakukan koordinasi dengan Kepala Sekolah terkait kegiatan tindak lanjut terhadap kegiatan pengabdian yang sudah dilaksanakan. Kegiatan tindak lanjut yang dilaksanakan 2 bulan setelah dilakukannya pelatihan terhadap guru (20 September 2021). Kegiatan ini bertujuan untuk melihat sejauh mana WQC digunakan dalam proses pembelajaran terutama sebagai alat evaluasi. 


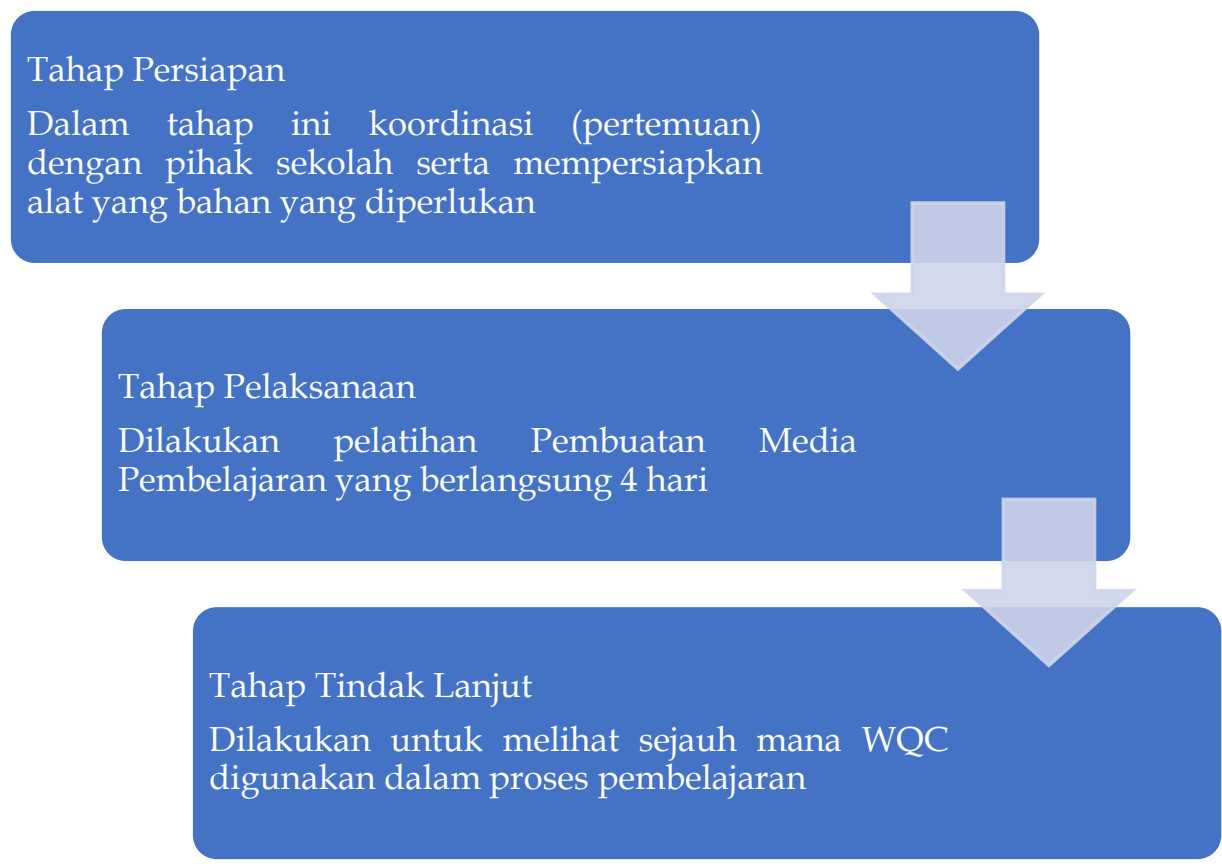

Gambar 1. Diagram Alur Pengabdian Masyarakat

\section{Hasil dan Pembahasan}

Kegiatan pelatihan yang didahului dengan tahap persiapan dimana tim pengabdian bertemu dengan Kepala Sekolah SMPS Katolik Aurora pada tanggal 27 Mei 2021 dimana Kepala Sekolah menyambut baik niat dari tim pengabdian dan menyebutkan pula bahwa pihak sekolah dalam hal ini guru-guru juga sangat membutuhkan pengetahuan dan ketrampilan dalam membuat soal-soal multimedia interaktif dikarenakan selama masa pandemic Covid-19 ini guru-guru hanya menggunakan media whatsapp untuk kegiatan pembelajaran.

Kegiatan pelatihan kemudian dilaksanakan dua hari beturut-turut yaitu pada tanggal 22 dan 23 Juli 2021. Dimana pada hari pertama tim pengabdian bersama pihak sekolah melakukan persiapan berupa penginstalan software WQC pada semua PC yang ada di Laboratorium Komputer dan pembagian modul mengenai penggunaan WQC sehingga guru-guru dapat mempelajari modul terlebih dahulu sebelum mencoba menggunakan WQC esok harinya.

Selanjutnya, pada hari kedua kegiatan diawali dengan pembukaan secara resmi oleh Kepala Sekolah. Setelah itu dilanjutkan dengan pemberian materi oleh tim pengabdian mengenai software WQC yang diawali pengenalan bagian-bagian dari software yang dapat dilihat pada Gambar 1. Pelatihan kemudian dilanjutkan dengan proses pembuatan soal menggunakan WQC berupa soal-soal sederhana yang bertujuan untuk memperkenalkan proses pembuatan soal kepada guru-guru. Adapun semua jenis soal yang disediakan pada $W Q C$ baik itu soal pilihan ganda, menjodohkaan, soal uraian dll semua diperkenalkan kepada Guru-guru. Setelah proses pembuatan soal selesai, guru-guru diberikan cara mengatur fitur soal yang sudah jadi baik dari segi tampilan, data yang ingin diperoleh guru seperti nama, kelas, mata pelajaran dll 
sampai pada pengaturan password jika ada. Kegiatan ini dilanjutkan dengan proses publikasi soal yang sudah dibuat dalam bentuk Flash Player yang dapat dimanfaatkan sebagai media belajar siswa dan diakhiri dengan memberikan kuesioner respon guru dalam mengikuti pelatihan.

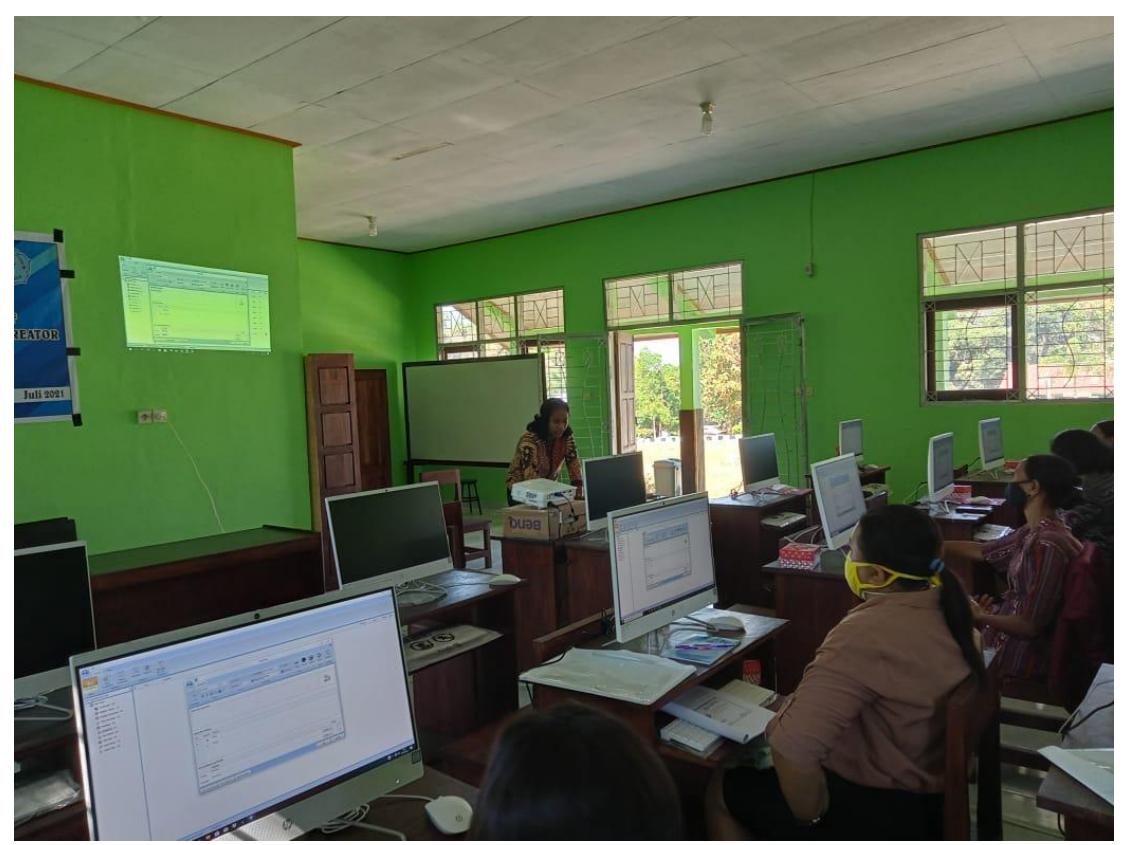

Gambar 2. Tim Pengabdian memberikan materi kepada peserta

Adapun hasil dari kuesioner adalah sebagai berikut:

1. Hampir seluruh guru belum pernah menggunakan WQC dimana dari 17 peserta, 15 peserta atau sebanyak $88,24 \%$ memberikan respon belum pernah menggunakan WQC.

2. Meskipun $70,59 \%$ atau sebanyak 12 orang guru membutuhkan waktu yang lama untuk membuat soal namun semua guru menilai software WQC ini menarik dan juga meyakini bahwa software ini dapat meningkatkan semangat siswa dalam menjawab soal ujian yang akan diberikan.

3. Semua guru juga menilai Software ini mudah digunakan dan akan menggunakannya dalam kegiatan belajar mengajar.

Namun, selain respon positif di atas, guru-guru menyatakan bahwa para guru cenderung mengalami kesulitan dalam membuat soal-soal perhitungan semisal untuk Mata Pelajaran Matematika ataupun soal-soal yang membutuhkan gambar/foto. 


\section{Hasil Respon Guru}

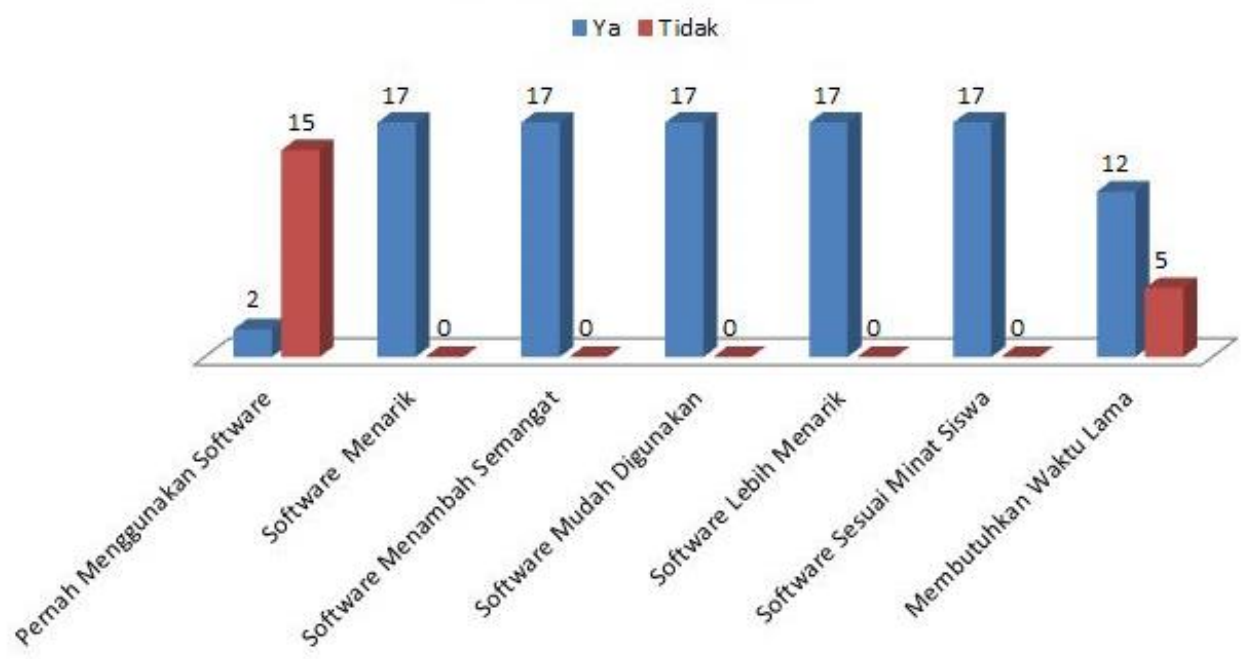

Gambar 3. Hasil Respon Siswa Terhadap Penggunaan WQC

Tahapan terakhir dari pelatihan ini adalah merupakan kegiatan tindak lanjut yang dilaksanakan pada tanggal 20 September 2021 dimana tim pengabdian melakukan pendampingan kepada beberapa guru yang telah dipilih untuk membuat soal yang sesuai dengan materi pelajaran yang telah diajarkan oleh guru yang bersangkutan. Soal yang dibuat adalah soal-soal sederhana yang akan diberikan kepada siswa sebagai pengenalan terhadap WQC. Adapun pada tahap tindak lanjut ini guru tidak mengalami kesulitan dalam pembuatan soal dan penggunaannya di kelas.

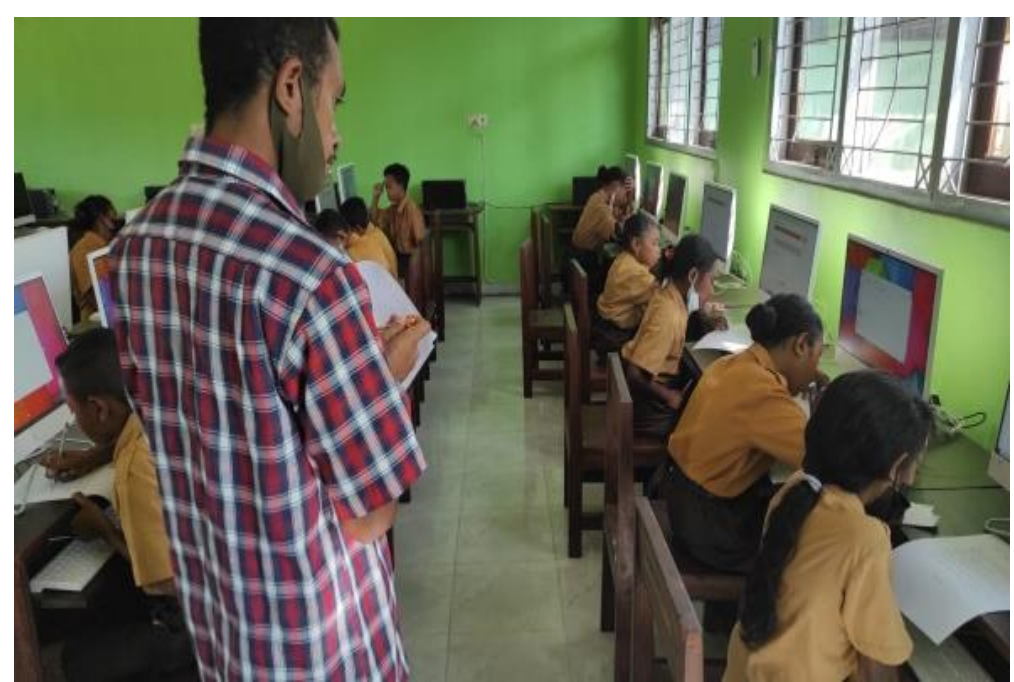

Gambar 4. Guru menggunakan software WQC dalam proses pembelajaran di kelas

Respon positif terhadap software $W Q C$ juga diperoleh dari siswa dimana terlihat pada Gambar 4 yaitu proses penyelesaian soal menggunakan $W Q C$, hampir semua siswa menyatakan bahwa software ini dapat menambah semangat siswa dalam menjawab 
soal-soal yang diberikan dan 13 siswa dari 14 siswa menyatakan bahwa software ini mudah digunakan. Selengkapnya dapat dilihat pada grafik berikut

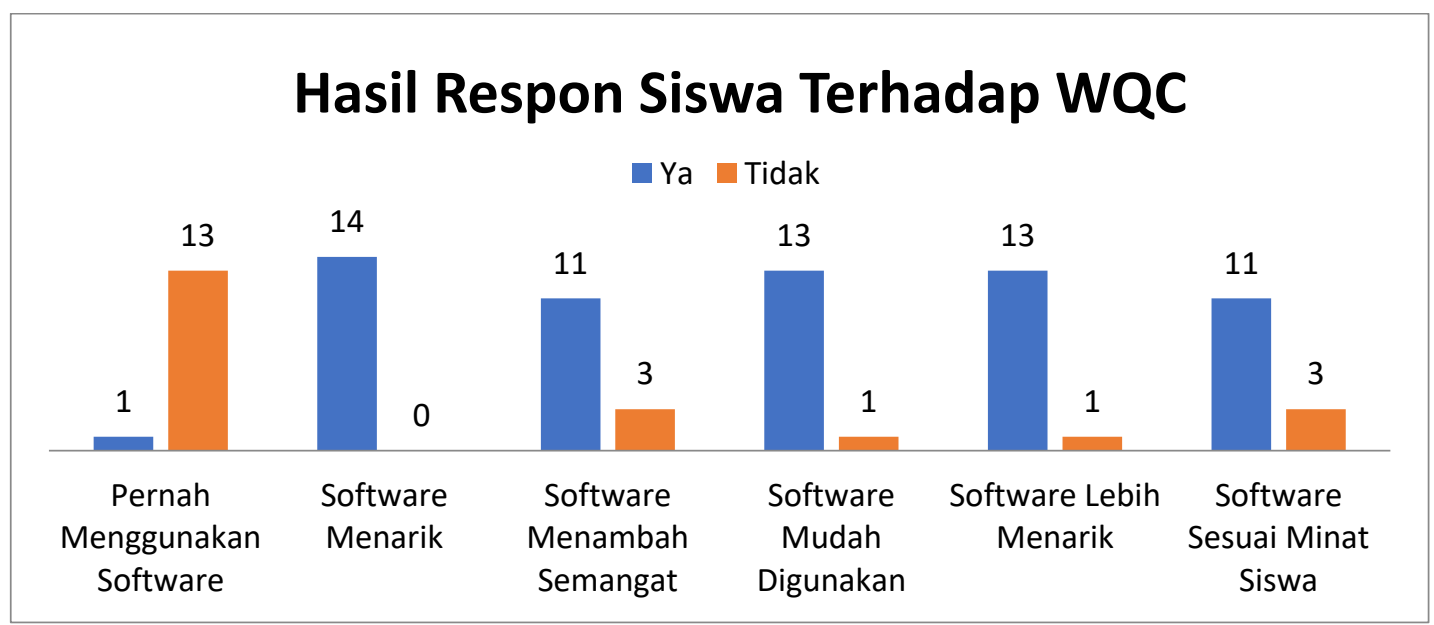

Gambar 5. Hasil Respon Siswa Terhadap Penggunaan WQC

Gambar 5 memperlihatkan bahwa sesuai dengan hasil observasi yang dinyatakan Kepala Sekolah yakni sebagian besar guru dan siswa belum pernah menggunakan software ini. Setelah diujicobakan kepada siswa diperoleh hasil bahwa software ini menarik, menambah semangat dan mudah digunakan serta lebih menarik dan sesuai dengan minat siswa dalam menyelesaikan soal.

Hal yang telah dipaparkan sebelumnya sejalan dengan yang diperoleh oleh (Adnan et al., 2018) dimana respon guru terhadap pelatihan media pembelajaran berbasi $W Q C$ adalah guru termotivasi dalam menyusun soal interaktif dengan WQC bahkan didapati bahwa pelatihan ini dapat meningkatkan pengetahuan dan ketrampilan dalam menyusun soal. Begitu pula dengan pelatihan WQC yang dilaksanakan oleh (Adi et al., 2021) dimana 90\% peserta merespon bahwa pelatihan memberikan manfaat pada peserta dalam hal pembuatan tes berbasis online.

\section{Simpulan dan Rekomendasi}

Kegiatan pengabdian telah dilakukan selama 4 hari yaitu pada tanggal 22 dan 23 Juli 2021 serta 20 September 2021 dan 1 Oktober 2021. Hasil kuesioner respon guru pada pengabdian hari kedua ini menunjukan bahwa semua guru belum pernah menggunakan WQC sebagai software pembuatan alat evaluasi. Hal positif dari kegiatan ini adalah guru-guru juga merasa memperoleh pengalaman baru membuat alat evaluasi yang lebih menarik. Meskipun 70,59\% guru membutuhkan waktu yang lama untuk membuat soal namun seluruhnya merasa software ini menarik dan mudah digunakan serta diyakini menambah semangat siswa ketika mengerjakan soal ujian. Kegiatan ini dilanjutkan pada kegiatan tindak lanjut untuk melihat sejauh mana guru telah memahami penggunaan WQC dan mengaplikasikannya pada siswa. Hal menarik dari respon siswa yakni ternyata sudah ada siswa yang pernah menggunakan WQC sebelumnya. Hasil respon siswa menunjukkan bahwa software ini dianggap mudah untuk digunakan dan lebih menarik jika dibandingkan dengan 
ujian tertulis. Hasil percobaan penggunaan alat evaluasi pada siswa juga memberikan hasil 78,57\% siswa merasa software ini dapat menambah semangat dalam mengerjakan soal dan $92,87 \%$ siswa merasa software ini menarik dan mudah digunakan serta sesuai dengan minat mereka.

\section{Penghargaan}

Kegiatan Pengabdian ini dibiayai oleh DIPA Unimor pada Skema Pengabdian Kepada Masyarakat Tahun 2021. Oleh karena itu penulis mengucapkan terima kasih kepada Universitas Timor yang telah mendanai keberlangsungan pengabdian ini. Terimakasih juga penulis sampaikan kepada SMPS Katolik Aurora sudah menerima penulis untuk melakukan pengabdian di sekolah ini.

\section{Daftar Pustaka}

Adi, P., Juniarta, K., Ramendra, D. P., Mahendrayana, G., \& Dewi, K. S. (2021). EVALUASI PEMBELAJARAN SECARA ONLINE MELALUI APLIKASI WONDERSHARE QUIZ CREATOR DI SMP N 1 GEROKGAK. 1030-1038.

Adnan, A., Hamka, L., \& Hs, S. B. (2018). Respon guru terhadap pelatihan pembuatan media pembelajaran berbasis TIK di Benteng Kepulauan Selayar. Seminar Nasional Pengabdian Kepada ..., 539-542. https://ojs.unm.ac.id/semnaslpm/article/viewFile/7807/4561

Candra Rolisca, R. U., \& Achadiyah, B. N. (2014). Pengembangan Media Evaluasi Pembelajaran Dalam Bentuk Online Berbasis E-Learning Menggunakan Software Wondershare Quiz Creator Dalam Mata Pelajaran Akuntansi Sma Brawijaya Smart School (Bss). Jurnal Pendidikan Akuntansi Indonesia, 12(2). https://doi.org/10.21831/jpai.v12i2.2706

Dafitri, H. (2017). Pemanfaatan Wondershare Quiz Creator Dalam Tes Berbasis Komputer. QUERY: Jurnal Sistem Informasi, 01(01), 8-18.

Kholifah, S., \& Rubhiyanti, R. (2018). Desain Evaluasi Mata Kuliah Technopreurship Menggunakan Wondershare Quiz Creator. EQUILIBRIA PENDIDIKAN : Jurnal Ilmiah Pendidikan Ekonomi, 3(2), 88. https://doi.org/10.26877/ep.v3i2.3498

Meryansumayeka, Virgiawan, M. D., \& Marlini, S. (2018). Pengembangan Kuis Interaktif Berbasis E-Learning Dengan Menggunakan Aplikasi Wondershare Quiz Creator Pada Mata Kuliah Belajar Dan Pembelajaran Matematika. Journal Pendidikan Matematika, 12(1), 29-42.

Purnanto, A. W., \& Mahardika, A. (2017). Pelatihan Pembuatan Soal Interaktif Dengan Program Wondershare Quiz Creator Bagi Guru Sekolah Dasar Di Kota Magelang. Warta LPM, 19(2), 141-148. https://doi.org/10.23917/warta.v19i2.2748 
Rahmawati, D. (2017). PEMANFAATAN WORDERSHARE QUIZ CREATOR DALAM PEMBUATAN SOAL-SOAL BAHASA ARAB Arabi : Journal of Arabic Studies. Journal of Arabic Studies, 2(1), 37-46.

Sefpratama, A., Niniwati, Khairi, A. (2015). Pengembangan Media Pembelajaran Interaktif Menggunakan Macromedia Flah Dan Wondershare Quiz Creator Dengan Materi Perangkat Peripheral Pada Siswa Kelas X Di Smk. Abstract of Undergraduate, Faculty of Education, Bung Hatta University. 2(2):1-10

Widarma, A., \& Saleh, K. (2020). Pelatihan Pembuatan Media Pembelajaran Menggunakan Power Point, Wonder Share Quiz Creator Dan Edmodo Di Smk Apipsu Medan. Jurnal Anadara Pengabdian Kepada Masyarakat., 2(1), 55-60. 